Full length Article

\title{
Regional and global integration of Asian stock markets
}

\author{
Wahbeeah Mohti $^{\mathrm{a}, *}$, Andreia Dionísio ${ }^{\mathrm{b}}$, Isabel Vieira ${ }^{\mathrm{a}}$, Paulo Ferreira ${ }^{\mathrm{b}, \mathrm{c}}$ \\ ${ }^{a}$ Universidade de Évora (Departamento de Gestão), Largo dos Colegiais, 2, 7000-903, Évora, Portugal \\ ${ }^{\mathrm{b}}$ CEFAGE-UE, IIFA, Universidade de Évora, Largo dos Colegiais, 2, 7000, Évora, Portugal \\ ${ }^{\mathrm{c}}$ Escola Superior Agrária de Elvas, Instituto Politécnico de Portalegre, Portugal
}

\section{A R T I C L E I N F O}

\section{JEL classification}

G0

G1

\section{Keywords:}

Emerging markets

Frontier markets

Stock market integration

Detrended cross correlation analysis (DCCA)

Gregory and Hansen cointegration test

\begin{abstract}
A B S T R A C T
This paper assesses the levels of regional and global stock market integration of emerging and frontier Asian countries. The long run relationships established amongst markets are investigated using Gregory and Hansen's cointegration tests and Detrended Cross Correlation coefficients. The results of the empirical analysis indicate that all considered emerging markets display some evidence of both global and regional integration. In the case of frontier markets, however, this is true solely for Pakistan and, to a lesser extent, for Vietnam. These results are of interest, inter alia, to international investors interested in expanding the geographical scope of portfolio diversification strategies.
\end{abstract}

\section{Introduction}

The integration of stock markets has distinct implications and its empirical evaluation may be of use in various contexts. Financial integration affects stock prices' comovements across countries (Bekaert et al., 2002) and highly integrated stock markets exhibit statistically significant long-term relationships (Cheng, 2000). Obstfeld's (1994) theoretical model indicated that international risk sharing improves resources' allocation and promotes economic growth. The empirical assessment by Korajczyk (1996) concurs in showing that the level of stock market integration is positively related to economic growth.

Market integration is also relevant for portfolio investors. According to the 'modern portfolio theory', diversification increases the return for a given level of risk, or decreases the risk for a given return. As different stock markets can be exposed to distinct factors, international diversification can enhance the advantages of domestic diversification (e.g. Grubel, 1968), provided that domestic and foreign markets are less than perfectly correlated (Masih and Masih, 1999). It is thus not surprising that the benefits from international portfolio diversification have decreased with market integration and the globalization of financial markets (see e.g. Cheung and Mak, 1992; Gilmore and McManus, 2002; Bessler and Yang, 2003; Kearney and Lucey, 2004; Alagidede, 2008).

Such developments enhance the interest in potentially more segmented markets, such as frontier markets (see Speidell and Krohne, 2007; Jayasuriya and Shambora, 2009) and thus the utility of empirical assessments of their level of integration with more traditional ones. Our work therefore contributes to the financial integration literature by both extending the geographical scope of existing empirical studies and adopting a robust methodological approach that takes into account statistical specificities of the utilized data often disregarded in this type of analysis. First, we study frontier markets, namely Pakistan, Bangladesh, Sri Lanka and Vietnam, which have been relatively less investigated, probably due to reasons related to data availability. Assessment of such

\footnotetext{
* Corresponding author.

E-mail addresses: beeah_awan@yahoo.com (W. Mohti), andreia@uevora.pt (A. Dionísio), impvv@uevora.pt (I. Vieira), pjsf@uevora.pt (P. Ferreira).
} 